\title{
A STUDY OF CLINICAL AND HAEMATOPATHOLOGICAL CORRELATION OF HAEMOLYTIC ANAEMIAS IN CHILDREN
}

\author{
K. Palaniappan ${ }^{1}$, V. Booma ${ }^{2}$ \\ ${ }^{1}$ Assistant Professor, Department of Paediatrics, Coimbatore Medical College, Coimbatore. \\ ${ }^{2}$ Associate Professor, Department of Paediatrics, Coimbatore Medical College, Coimbatore.
}

\section{ABSTRACT}

Anaemia is a manifestation of disease, not a disease in itself. Anaemia is a frequent laboratory abnormality in children. As many as 80 children in developing countries will be anaemic at some point by the age of 18 years. Most children with anaemia are asymptomatic, but have abnormal lab data on routine screening. Physical examination is also many a times normal. Detection and diagnosis are essential for rational analysis and management. Among the anaemias, Haemolytic anaemias are unique. The aetiology is diverse and many hereditary and acquired disorders play a role. Clinical presentation depends on the onset of erythrocyte destruction. The morbidity depends on the aetiology of haemolysis. This study focuses on the prevalence, age of presentation and clinical profile of haemolytic anaemia in children and will help in early diagnosis and planning of appropriate treatment.

\section{AIMS AND OBJECTIVES OF STUDY \\ To study the prevalence of various types of Haemolytic anaemia in children admitted in Paediatric wards at a tertiary care Hospital. To study the clinical profile, age at first presentation and the aetiology of the hereditary haemolytic anaemia and to study the utility of laboratory procedures in the diagnosis of hereditary haemolytic anaemia. To study the complications, treatment protocols and the response to treatment in hereditary haemolytic anaemia.}

\section{METHODOLOGY}

Study Design: Prevalence study, Study Place: Department of Paediatrics, Coimbatore Medical College, Coimbatore, Study Period: 18 months (Nov 2012 - April 2014).

\section{INCLUSION CRITERIA}

The sample consisted of children aged 1 month to 17 years, presenting with clinical symptoms and signs suggestive of haemolytic anaemia and those with peripheral blood smear suggestive of haemolysis.

\section{EXCLUSION CRITERIA}

Neonates were excluded from the study.

\section{MANOEUVRE}

In the present hospital-based study, the prevalence of various types of haemolytic anaemia in children attending Coimbatore Medical College and Hospital was studied. In children diagnosed with hereditary haemolytic anaemia the clinical profile, complications, utility of the diagnostic procedures, treatment protocols and the response to the treatment were studied.

\section{RESULTS/CONCLUSION}

In the present hospital-based prevalence study, 52 children were diagnosed as having Haemolytic anaemia. In those children diagnosed as hereditary haemolytic disorders, the age at first presentation, clinical profile, complications, treatment protocols and response to the treatment were studied. In our study, the youngest child was 3-month-old female and the oldest was 3-year-old male. Most of the children were presented in the age group between 3 months to 12 months - 8 cases (66.66\%). Mean age at presentation is 9 months. In the present study, the frequency of Hb-S related disorders was high constituting $57.57 \%$ followed by Thalassemia syndromes constituting $39.36 \%$. Average age at presentation of Thalassemia major was 9 months; Sickle cell anaemia 6 yrs.; Sickle cell trait 4 yrs. and Sickle thalassemia 5.5 yrs. Male: Female ratio for Thalassemia major was 2:1; Male: Female ratio for Sickle cell anaemia was 26:1. The common mode of presentation/complication for Thalassemia major was anaemia with congestive cardiac failure; vaso-occlusive crisis for sickle cell anaemia and anaemia for sickle cell disease. Family history of consanguinity was positive in $69.69 \%$ of cases. When growth parameters were studied in children with beta thalassemia major, growth retardation was observed in $75 \%$ of cases; and in sickle cell disorders $78.4 \%$ of children had growth retardation. Peripheral smear evidence of haemolysis was positive in $90.9 \%$ cases suggesting that as the most useful method for screening. In children diagnosed as having Thalassemia major, $72 \%$ received 15 blood transfusions at the age of $0-2$ yrs. and in children diagnosed as having Sickle cell disorders 50\% received 1st blood transfusion at the age of $3-5$ yrs. In those children receiving chelation therapy, side effect reported was neutropenia.

\section{KEYWORDS}

Anaemia, Thalassemia, Haemolytic, Sickle Cell.

HOW TO CITE THIS ARTICLE: Palaniappan K, Booma V. A study of clinical and haematopathological correlation of haemolytic anaemias in children. J. Evolution Med. Dent. Sci. 2016;5(69):4984-4988, DOI: 10.14260/jemds/2016/1132

\section{INTRODUCTION}

Anaemia is a frequent laboratory abnormality in children. As many as $80 \%$ children in developing countries will be anaemic at some point by the age of 18 years.[1] Most children with anaemia are asymptomatic and have an abnormal value or haematocrit level on routine screening.

Financial or Other, Competing Interest: None.

Submission 17-07-2016, Peer Review 15-08-2016,

Acceptance 22-08-2016, Published 27-08-2016.

Corresponding Author:

Dr. V. Booma,

\#46, 50 Feet Road,

Krishnasamy Nagar, Ramanathapuram,

Coimbatore-641045.

E-mail: boomavmohan@yahoo.co.in

DOI: $10.14260 /$ jemds/2016/1132
The physical examination is important, but will be unremarkable in most children with anaemia. Detection and diagnosis of anaemia are frequently the focus of attention in the care of the patients, because accurate quantification is not difficult to achieve and rational analysis of the problem is possible. Anaemia is a manifestation of disease, not a disease in itself.[2]

The term "Haemolytic Anaemia" is limited to conditions in which the rate of red cell destruction is accelerated and the ability of the bone marrow to respond to the stimulus is unimpaired. The aetiology of haemolysis is diverse and it is the final event triggered by a number of hereditary and acquired disorders. Clinical presentation depends on whether the onset of haemolysis is gradual or abrupt and on the onset of 
erythrocyte destruction. The morbidity is dependent on the aetiology of haemolysis and the underlying disorder. This study focuses on the prevalence, age of presentation and clinical profile of haemolytic anaemia in children and will help in early diagnosis and planning of appropriate treatment.

\section{AIMS AND OBJECTIVES OF STUDY \\ Primary Objective}

To study the prevalence of various types of Haemolytic anaemia in children admitted in Paediatric wards at a tertiary care hospital.

\section{Secondary Objective}

To study the clinical profile, age at first presentation and the aetiology of the hereditary haemolytic anaemia and to study the utility of laboratory procedures in the diagnosis of hereditary haemolytic anaemia and to study the complications, treatment protocols and the response to treatment in hereditary haemolytic anaemia.

\section{METHODOLOGY}

Study Design: Prevalence study.

Study Place: Department of Paediatrics, Coimbatore Medical College, Coimbatore.

Study Period: 18 months (Nov 2012-April 2014).

\section{STUDY POPULATION}

\section{Inclusion Criteria}

The sample consisted of children aged 1 month to 17 years, presenting with clinical symptoms and signs suggestive of haemolytic anaemia and those with peripheral blood smear suggestive of haemolysis.

\section{Exclusion Criteria}

Neonates were excluded from the study.

In these children further investigations for the aetiological diagnosis of haemolytic anaemia was done and prevalence of various types was studied. In the children diagnosed as having hereditary haemolytic disorders, the clinical profile, complications, treatment protocols and the response to the treatment were studied.

\section{MATERIALS AND METHODS}

In the present hospital-based study, the prevalence of various types of haemolytic anaemia in children attending Coimbatore Medical College and Hospital was studied. In children diagnosed with hereditary haemolytic anaemia, the clinical profile, complications, utility of the diagnostic procedures, treatment protocols and the response to the treatment were studied.

The children attending the hospital with hereditary haemolytic anaemia were included in the study. The clinical and laboratory findings were analysed; new-born were excluded children.

\section{The Data Obtained were Analysed in SPSS Version 16} Software as follows

- Features of study population (Age, sex).

- Percentage of types of Haemolytic Anaemia.

- Age at first presentation of Thalassemia major.
- Mode of presentation of Thalassemia major and Sickle cell anaemia.

- Quantification of Haemoglobin variants based on HPLC analysis.

- Age distribution of children at $1^{\text {st }}$ transfusion.

- Distribution of patients according to number of transfusions and clinical data of Thalassemia major.

\section{RESULTS}

In the present hospital-based prevalence study, 52 children were diagnosed as having haemolytic anaemia. In those children diagnosed as hereditary haemolytic disorders, the age at first presentation, clinical profile, complications, treatment protocols and response to the treatment were studied. In our study the youngest child was 3-month old female and the oldest was 3-year-old male. Most of the children were presented in the age group between 3 months to 12 months - 8 cases (66.66\%). Mean age at presentation is 9 months.

\begin{tabular}{|c|c|c|}
\hline Types of Haemolytic Anaemia & No. of Cases & \% \\
\hline Hereditary Haemolytic Anaemia & & \\
\hline Thalassemia Major & 12 & $23.07 \%$ \\
\hline Thalassemia Minor & 1 & $1.97 \%$ \\
\hline Sickle Cell Anaemia & 11 & $21.15 \%$ \\
\hline Sickle Cell Trait & 4 & $7.69 \%$ \\
\hline Sickle Thalassemia & 4 & $7.69 \%$ \\
\hline $\begin{array}{c}\text { Hereditary Persistence } \\
\text { of Foetal Haemoglobin }\end{array}$ & 1 & $1.92 \%$ \\
\hline Acquired Haemolytic Anaemia & 17 & $32.69 \%$ \\
\hline \multicolumn{2}{|c|}{ Malaria } & 2 \\
\hline Autoimmune Haemolytic Anaemia & Types of Haemolytic Anaemia \\
\hline \multicolumn{2}{|c|}{} \\
\hline
\end{tabular}

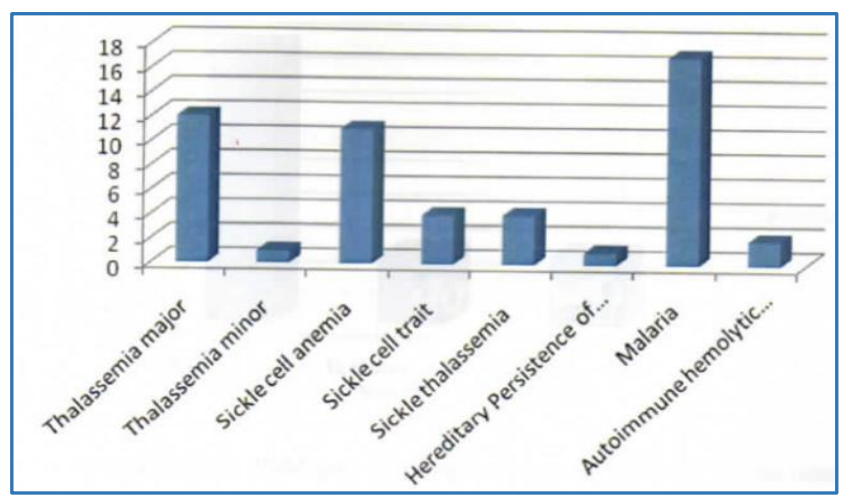

Types of Haemolytic Anaemia

\begin{tabular}{|c|c|c|}
\hline Age in Months & No. of Cases & Percentage \\
\hline $0-12$ & 8 & $66.66 \%$ \\
\hline $13-24$ & 2 & $16.66 \%$ \\
\hline $25-36$ & 2 & $16.66 \%$ \\
\hline \multicolumn{3}{|c|}{$\begin{array}{c}\text { Age at First Presentation } \\
\text { with Thalassemia Major }\end{array}$} \\
\hline
\end{tabular}




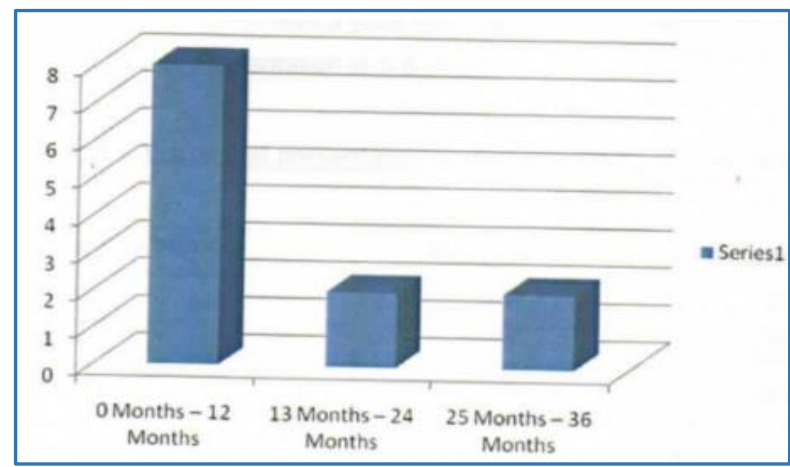

Age at First Presentation with Thalassemia Major

\section{MODE OF PRESENTATION}

\begin{tabular}{|c|c|c|}
\hline Clinical Features & No. of Cases & Percentage \\
\hline Pallor, Breathlessness (CHF) & 8 & $66.66 \%$ \\
\hline Pallor & 3 & $25 \%$ \\
\hline Chronic Cough & 1 & $8.3 \%$ \\
\hline \multicolumn{3}{|c|}{ Mode of Presentation - Thalassemia Major } \\
\hline
\end{tabular}

\begin{tabular}{|c|c|c|}
\hline Clinical Features & No. of Cases & Percentage \\
\hline Arthralgia & 5 & $45.45 \%$ \\
\hline Pallor & 2 & $18.18 \%$ \\
\hline Pallor Mass Per Abdomen & 1 & $9 \%$ \\
\hline Pallor, Breathlessness (CHF) & 1 & $9 \%$ \\
\hline Fever, Chest Pain & 1 & $9 \%$ \\
\hline Pallor, Arthralgia & 1 & $9 \%$ \\
\hline
\end{tabular}

\begin{tabular}{|c|c|c|c|c|c|}
\hline $\begin{array}{c}\text { Hb } \\
\text { Variant }\end{array}$ & $\begin{array}{c}\text { Thalassemia } \\
\text { Major }\end{array}$ & $\begin{array}{c}\text { Thalassemia } \\
\text { Minor }\end{array}$ & $\begin{array}{c}\text { Sickle Cell } \\
\text { Anaemia }\end{array}$ & $\begin{array}{c}\text { Sickle } \\
\text { Cell } \\
\text { Disease }\end{array}$ & HPFH \\
\hline Hb A (\%) & $0.1-81.1$ & 93.9 & $0.0-34.9$ & $24.3-74.2$ & 0.4 \\
\hline $\begin{array}{c}\mathrm{Hb} \mathrm{A2} \\
(\%)\end{array}$ & $2-3.8$ & 5.7 & $1.0-7.6$ & $2.8-4.7$ & 0.0 \\
\hline $\mathrm{Hb} \mathrm{F} \mathrm{( \% )}$ & $17.9-97.9$ & 0.5 & $7.3-42.7$ & $0.7-18.9$ & 99.6 \\
\hline Hb S (\%) & 0.0 & 0.0 & $51.0-83.3$ & $22.3-58.7$ & 0.0 \\
\hline \multicolumn{5}{|c|}{$\begin{array}{c}\text { Quantification of Haemoglobin Variants } \\
\text { Based on HPLC Analysis }\end{array}$} \\
\hline
\end{tabular}

\begin{tabular}{|c|c|c|c|}
\hline Age at 1st Transfusion & $\mathbf{0 - 2}$ yrs. & 3-5 yrs. & 6-13 yrs. \\
\hline $\begin{array}{c}\text { No of Children with } \\
\text { Thalassemia }\end{array}$ & 8 & 3 & - \\
\hline $\begin{array}{c}\text { No. of Children with } \\
\text { Sickle Cell Disorders }\end{array}$ & 2 & 9 & 7 \\
\hline \multicolumn{3}{|c|}{ Age Distribution of Children at 1 ${ }^{\text {st }}$ Transfusion } \\
\hline
\end{tabular}

$72 \%$ of children with Thalassemia major received $1{ }^{\text {st }}$ blood transfusion at the age of $0-2$ yrs. and $28 \%$ at the age of 3-5 yrs.; $11.11 \%$ of children with sickle cell disorders received $1{ }^{\text {st }}$ blood transfusion at the age of $0-2$ yrs.; $50 \%$ at the age of 3-5 yrs.; and $38.8 \%$ at the age of $6-13$ yrs.

\begin{tabular}{|c|c|c|c|c|c|c|c|c|}
\hline $\begin{array}{c}\text { No. of } \\
\text { Transfusions }\end{array}$ & T1 & T2 & T3 & T4 & T5 & T6 & T7 & $\begin{array}{l}\text { T8 \& } \\
\text { More }\end{array}$ \\
\hline No. of Patients & - & 1 & 5 & 2 & - & - & - & 3 \\
\hline Hepatomegaly & - & 1 & 4 & 2 & - & - & - & 3 \\
\hline Splenomegaly & - & 1 & 4 & 2 & - & - & - & 3 \\
\hline \multicolumn{9}{|c|}{ Distribution of Patients According to No. of } \\
\hline
\end{tabular}

In children diagnosed as having Thalassemia major, 90.9\% had hepatosplenomegaly.

\section{DISCUSSION}

Prevalence of Various Types of Haemolytic Anaemia

In the present study, 12 children were diagnosed as having Thalassemia major (23.07\%) and 1 child was diagnosed as having Thalassemia minor $(1.92 \%)$. Chatterjee JB, et al reported the prevalence of Thalassemia as 3.5 to $14.9 \%$ in India. [3] Banerjee et al reported that in India prevalence of Thalassemia minor varies between 1 and $17 \%$ in normal population. ${ }^{[4]}$ In the present study, 11 children were diagnosed as having Sickle cell anaemia (21.15\%) and 4 children were diagnosed as Sickle cell trait (7.69\%). R.S. Balgir reported the distribution of Sickle cell disorders in different states of India and in Andhra Pradesh; the distribution was reported as 1 to $35.7 \% .{ }^{[5]}$

In our study, 11 children were diagnosed as Sickle cell anaemia out of total 16 cases of Sickle cell disorders (68.75\%) and 4 children were diagnosed as Sickle cell trait (36.36\%). Kamble $\mathrm{M}$ et al reported similar findings - Sickle cell anaemia constituted $61.6 \%$ and Sickle cell trait constituted $38.4 \%$ in total Sickle cell disorders.[6] In the present study, 17 children were diagnosed as having Malaria (32.69\%).

The prevalence of Malaria was reported as $58.6 \%$ in India by Singh $\mathrm{N}$ et al.[7] Mohapatra MK reported that severe anaemia was the presenting feature in $6.9 \%$ of patients suffering from Malaria.[8] In our study, 2 children were diagnosed as having Autoimmune haemolytic anaemia (3.84\%). One of the children was diagnosed previously as having Systemic lupus erythematosus. Sultan SM et al reported that $6.6 \%$ of children with SLE manifested with severe haemolytic anaemia.[9]

\section{Age at First Presentation}

In the present study most of the children diagnosed as Thalassemia major, first presented at the age between 3 to 12 months. In our study in children with Sickle cell anaemia, $63.63 \%$ first presented below the age of 6 yrs. This is in accordance with the study results of Kamble $\mathrm{M}$ et al, who reported that $62 \%$ of children were presented below the age of 5 yrs. In our study, average age at first presentation in Sickle cell anaemia was 6 yrs. This is in accordance with the study result of Patel $A B$ et al, who reported the average age at presentation was $7.05 \pm 3.26$ yrs. ${ }^{[10]}$

\section{Sex Distribution}

In the present study, in children diagnosed as having Thalassemia major, the Male:Female ratio was $2: 1$. The study of D. Shaligram et al showed the M:F ratio of 1.421.[11] Sex distribution of Sickle cell anaemia in the present study showed the M:F ratio of 2.6:1. M:F ratio for Sickle cell trait was 1:1. Kamble M et al reported the M:F ratio of 1.65:1 in Sickle cell anaemia and 1.71:1 in Sickle cell trait.[6]

\section{Frequency of Complications}

In the present study, the frequency of congestive heart failure in Thalassemia major is $66.66 \%$. D. Shaligram et al reported that congestive heart failure due to Thalassemia and its treatment was present in $35.8 \%$ of children.[11] In the present study, Growth retardation was reported in $75 \%$ of Thalassemia patients. Banerjee J. et al reported that $71 \%$ of children suffering from Thalassemia showed growth retardation. ${ }^{[4]}$ In the present study in children with Thalassemia major, Thalassemic facies was present in 9 
children out of 12 [75\%]. In the study of D. Shaligram et al, it was reported that Thalassemic facies was present in $89.7 \%$ of children.[11]

\section{Comparison of Frequency of Complications in Children with Thalassemia Major}

In this study, the frequency of vaso-occlusive crisis in Sickle cell anaemia was 54\%. Kamble et al reported that vasoocclusive crisis $(23.2 \%)$ was the commonest crisis. Serjeant GR et al also reported that vaso-occlusive crisis is the most common and is the hallmark of patients with sickle cell disease. ${ }^{[12]}$ In the present study, the frequency of dactylitis was more in the age group of $1-5$ yrs. constituting $62.5 \%$ of the children. This is in accordance with the study result of Stevens MCG et al who reported that dactylitis occurs almost entirely in the first 4 years of life with a peak incidence at approximately 1 year of age.[13] In the present study, the mean values of $\mathrm{Hb} \mathrm{F}$ in HPLC analysis for Sickle cell disorders were reported as follows: For Sickle cell anaemia - 19.8\% for Sickle cell disease $-8.76 \%$. R. S. Balgir reported the mean values of $\mathrm{Hb} \mathrm{F}$ in Sickle cell anaemia as 10.4 and in Sickle cell disease as $6.6 \%$.

\section{Treatment Protocol}

In the present study in children diagnosed as having Thalassemia major, $72 \%$ received 1 st blood transfusion at the age of 0-2 yrs. The range of number of transfusions was 2-25. Mean age of patients was $1.3 \mathrm{yrs}$.; and in children diagnosed as having Sickle cell disorders $50 \%$ received 1 st blood transfusion at the age of 3-5 yrs. The range of number of transfusions was 2-10. Mean age of patients was 5.5 yrs.[14] in the present study. With blood transfusions, 17 children developed febrile reactions (58.62\%), one child developed allergic reaction (3.4\%).[11] In the present study, 2 children with Thalassemia major were under chelation therapy (Oral Deferiprone).[15] The complication of neutropenia was observed in one of them.[16]

\section{SUMMARY}

In this study, 52 children aged from 1 month to 17 years presenting with clinical symptoms and signs suggestive of haemolytic anaemia were evaluated for the aetiological diagnosis of haemolytic anaemia. The children were diagnosed as having the following types of haemolytic anaemia: Thalassemia major constituted 12 cases (36.36\%); Thalassemia trait, 1 case (3\%); Sickle cell anaemia, 11 cases (3.33\%); Sickle cell trait, 4 cases (12.12\%); Sickle thalassemia, 4 cases (12.12\%); Hereditary persistence of foetal haemoglobin, 1 case (3\%); Malaria, 17 cases (32.69\%); and Autoimmune haemolytic anaemia, 2 cases $(3.84 \%)$. In those children diagnosed as having hereditary haemolytic anaemia the clinical profile, complications, treatment protocol followed and the response to the treatment were studied and the results were compared with those of similar studies. Age wise distribution of Thalassemia major. Most of the children first presented at the age of 3 months to 12 months - 8 cases $(66.66 \%)$. Average age at presentation is 9 months. Average age at presentation of Sickle cell anaemia is 6 years. For Thalassemia major, Male:Female ratio is $2: 1$; for sickle cell anaemia, 2.6:1; for Sickle cell trait, $1: 1$ and for Sickle thalassemia, $1: 3$

\section{CONCLUSION}

In the present hospital-based prevalence study, 52 children were diagnosed as having haemolytic anaemia and in those 33 were diagnosed as having hereditary haemolytic anaemia. The results were compared with those of similar studies. The following conclusions are drawn from the study:

- In the present study, the frequency of $\mathrm{Hb}-\mathrm{S}$ related disorders was high constituting $57.57 \%$ followed by Thalassemia syndromes constituting $39.36 \%$.

- $\quad$ Average age at presentation of Thalassemia major was 9 months; Sickle cell anaemia 6 yrs., Sickle cell trait 4 yrs. and Sickle thalassemia 5.5 yrs.

- Male:Female ratio for Thalassemia major was 2:1; Male:Female ratio for Sickle cell anaemia was 26:1.

- The common mode of presentation/complication for Thalassemia major was anaemia with congestive cardiac failure; vaso-occlusive crisis for sickle cell anaemia and anaemia for sickle cell disease.

- Family history of consanguinity was positive in $69.69 \%$ of cases.

- When growth parameters were studied in children with beta thalassemia major, growth retardation was observed in $75 \%$ of cases; and in Sickle cell disorders $78.4 \%$ of children had growth retardation.

- $\quad$ Peripheral smear evidence of haemolysis was positive in $90.9 \%$ cases suggesting that as the most useful method for screening.

- In children diagnosed as having Thalassemia major, $72 \%$ received 15 blood transfusions at the age of $0-2$ yrs. and in children diagnosed as having Sickle cell disorders 50\% received 1 st blood transfusion at the age of 3-5 yrs.

- In those children receiving chelation therapy, side effect reported was neutropenia.

\section{REFERENCES}

1. Martin PH, Pearson HA. The anemias. In: Oski FA, ed. Principles and practices of paediatrics. $21^{\text {st }}$ ed. Philadelphia: Lippincott 1994:1657.

2. Wintrobe MM. The diagnostic and therapeutic approach to hematologic problems. $10^{\text {th }}$ ed. Richard GL, Foerster O, John PG. Wintrobe's Clinical Hematology. Baltimore: Lippincott 1999:574.

3. Chatterjee JB. Hemoglobinopathies: g6pd deficiency and allied problems in the Indian sub-continent. Bull World Health Organ 1966;35(6):837-56.

4. Banerjee J, Saha S, Dasgupta I, et al. Growth in length \& weight of thalassemic children in West Bengal, India-a prospective study. Parasmani, Roland, Hauspie. Perspectives in human growth, development and maturation. Springer Netherlands 2001:27-341.

5. Balgir R. Epidemiology, population health genetics and phenotypic diversity of sickle cell disease in India. The lnternet Journal of Biological Anthropology 2007;1(2).

6. Kamble M, Chaturvedi P. Epidemiology of sickle cell disease in a rural hospital of central India. Indian Pediatrics 2000;37(4):391-6.

7. Singh N, Chand SK, Mishra AK, et al. Epidemiology of malaria in an area of low transmission in central India. Am J Trop Med Hyg 2006;75(5):812-6.

8. Mohapatra MK. The natural history of falciparum malaria-a prospective study. J Assoc Physicians India 2006;54:848-53. 
9. Sultan SM, Begum S, Lsenberg DA. Prevalence, patterns of disease and outcomes in patients with SLE who develop severe hematological problems. Rheumatology (Oxford) 2003;42(2):230-4.

10. Patel AB, Athavale AM. Sickle cell disease in central India. Indian Journal of Pediatrics 2004;71(9):789-93.

11. Shaligram D, Girimaji SC, Chaturvedi SK. Psychological problems \& quality of life in children with thalassemia. Indian Journal of Pediatrics 2007;74(8):727-30.

12. Serjeant GR, Ceulaer CD, Lethbridge R, et al. The painful crisis of homozygous sickle cell disease: clinical features. Br J Haemeatol 1994;87(3):586-91.
13. Stevens MC, Padwick M, Serjeant GK. Observations on the natural history of dactylitis in homozygous sickle cell disease. Clin Pediatr (Phila) 1981;20(5):311-7.

14. Borga-Pignatti C, Rugolotto $S$, De Stefano P, et al. Survival complications in patients with thalassemia major treated with transfusion \& deferoxamine. Haematologica 2004;89(10):1187-93.

15. Naithani R, Chandra J, Sharma S. Safety of oral iron chelator deferiprone in young thalassemias. Eur J Haematol 2005;74(3):217-20.

16. Tshilolo LM, Mukendi RK, Wembonyama SO. Blood transfusion in Congolese patients with sickle cell anemia. Indian Journal of Pediatrics 2007;74(8):735-8. 